\title{
Reproductive biology of free-living and commensal polynoid polychaetes at the Lucky Strike hydrothermal vent field (Mid-Atlantic Ridge)
}

\author{
Cindy Lee Van Dover*, Jennifer Trask, Jennifer Gross, Ann Knowlton \\ Institute of Marine Science, University of Alaska Fairbanks, Fairbanks, Alaska 99775-7220, USA
}

\begin{abstract}
We examined the reproductive biology of a polynoid polychaete commensal in mussel mantle cavities (Branchipolynoe cf. seepensis) and of a polynoid polychaete that is free-living among those same mussels (Opisthotrochopodus n. sp.). Specimens of each species were collected from 2 different sites (Eiffel Tower and Sintra; $400 \mathrm{~m}$ apart) within the Lucky Strike hydrothermal field. Both species exhibit sexual dimorphism, with varying numbers of pairs of nephridial papillae. In $B$. cf. seepensis, sexual dimorphism also includes a difference in size, with females larger than males. Contrary to our expectations, the reproductive biology of both species is very similar. Sperm heads are elongate, suggesting some mode of sperm transfer or storage. Females of both species contain mature sperm and there is evidence of internal fertilization. Maximum oocyte diameters are large $(>390 \mu \mathrm{m})$, from which we infer non-planktotrophic development; oogenesis is intraovarian and suggests rapid oocyte development. Oocyte size-frequency distributions and population size structure suggest a pattern of asynchronous gametogenesis. We found no substantive evidence for site-specific variations in reproductive biology in either species.
\end{abstract}

KEY WORDS: Hydrothermal vent - Polychaete reproduction Polynoid

\section{INTRODUCTION}

Soon after the discovery of hydrothermal vent communities in the deep sea, biologists recognized that the ephemeral and insular characteristics of this environment do not dictate a single reproductive strategy among invertebrate types (e.g. Lutz et al. 1984, Van Dover et al. 1985), despite early expectations of $r$-type ecological strategies including small and abundant progeny with significant dispersal capabilities (e.g. Desbruyères \& Laubier 1983). For the limited number of vent taxa investigated to date, most species are inferred to have lecithotrophic development, based primarily on egg size (reviewed in Jollivet 1996). Apparent exceptions include mytilid mussels (Bathymodiolus spp.; Berg 1985, Le Pennec \& Benninger 1997) and some bythograeid crabs and shrimp (e.g. Bythogrea thermydron; Van Dover et al. 1985) which

- Present address: Biology Department, The College of William \& Mary, Williamsburg, Virgina 23187-8795, USA.

E-mail: cindy_vandover@wm.edu produce large numbers of small eggs that presumably develop into planktotrophic larvae. While lecithotrophy is often associated with limited dispersal in shallow-water species, the uniformly cold environment of the deep sea may retard larval development, making it difficult to be certain that lecithotrophic development restricts dispersal (Lutz et al. 1980, 1984). A few vent species undergo direct development, forgoing a dispersive larval stage altogether (e.g. amphipod species; France et al. 1992).

As in other ecosystems, phylogenetic constraints within some taxonomic groups at vents (e.g. galatheid squat lobsters [Van Dover \& Williams 1991] and archaeogastropod mollusks [Lutz et al. 1984]) seem to prescribe certain inflexible reproductive characteristics among species, especially with regard to planktotrophic development. Other reproductive characteristics, such as temporal patterns of gametogenesis, or even direct versus lecithotrophic development, may be more flexible.

Even within higher taxa (families and subfamilies) that are exclusive to hydrothermal vent ecosystems, 
there is no consistent reproductive pattern that might indict a particular environmental aspect of hydrothermal vents as an overwhelming selective pressure. The best example of this may be within the polychaete family Alvinellidae, where reproductive ecologies may have radiated within sympatric and allopatric species of the genus Paralvinella to include pseudocopulation and broadcast fertilization, synchronous and asynchronous gametogenesis, and direct and lecithotrophic development (McHugh 1989, Zal et al, 1995). We use the terms 'synchronous' and 'asynchronous' gametogenesis to describe the condition of developing gametes within individuals and among individuals within a population without making inferences regarding spawning patterns (i.e. sensu Eckelbarger \& Watling 1995). Polychaetes in general seem more flexible in adapting variations on reproductive themes than some other invertebrate groups (Wilson 1991, Eckelbarger \& Watling 1995). Apart from siphonostome copepods in the family Dirivultidae, the polychaete family Polynoidae demonstrates the greatest radiation at the species level within the vent ecosystem, with 33 species described to date (Tunnicliffe et al. 1998). This radiation seems likely to accommodate a variety of reproductive ecologies; indeed, reproductive flexibility may in part account for the radiation.

To initiate a long-term study of the comparative reproductive biology of the Polynoidae, we compare the reproductive characteristics of 2 polynoid polychaete species expected to demonstrate adaptations associated with their particular life habits rather than with the more general condition of habitat ephemerality or insularity. One of these species, Opisthotrochopodus n. sp. (Pettibone pers. comm.), is a small (max. length $\sim 10 \mathrm{~mm}$ ), free-living polychaete that forages among mytilid mussels (Bathymodiolus sp.) that dominate the Lucky Strike hydrothermal field on the Mid-Atlantic Ridge. The other species, Branchipolynoe cf. seepensis, reaches much larger sizes (max. length $-30 \mathrm{~mm}$ ) and lives as a commensal within the mantle cavity of the Lucky Strike mussels. Opisthotrochopodus $\mathrm{n}$. sp. and $B$. cf. seepensis belong to 2 different subfamilies of the Polynoidae (Branchinotogluminae and Branchipolynoinae, respectively). These subfamilies are so far restricted to deep-sea reducing environments, with so little known about their reproductive biology that it is impossible to make any inferences about phylogenetic constraints at the subfamilial level. Other subfamilies in the Polynoidae include representatives that have free-spawning, planktotrophic larvae (Bhaud \& Cazaux 1987, Reish 1980). At least 1 shallowwater polynoid species (Harmothoe imbricata) is reported to brood its young on the outside of its body and then release them to disperse as planktotrophic larvae (Blake 1975). Our sampling strategy of multiple repli- cates from 2 discrete sites within the Lucky Strike hydrothermal field allows us to investigate both sitespecific population structure and spatial variation in gametogenesis within each polynoid species.

Based on preliminary measures of size differences in 2 morphs of the commensal polynoid species (reported here), we suspected that this species was likely to be a protandric hermaphrodite. Small males, we reasoned, would be adept at moving between mussels while females would benefit from being egg machines, growing large and fecund within mantle cavities of mussels and expending little energy on foraging given the ready supply of food and experiencing low risk of predation. This would be a classic example of the 'sizeadvantage' hypothesis which suggests that the ability to change sex is favored when the relation between age/size and reproductive success differs between the 2 sexes (e.g. Berglund 1990). We also expected a priori that gametogenesis in the commensal species would be asynchronous and that females would invest energy in large, yolky eggs, since they live in a buffered environment with a continual supply of food. In contrast, we expected separate sexes in the free-living polynoid species and, because of the need by the female to expend energy in foraging and predator avoidance, small eggs with relatively little yolk. Synchronous versus asynchronous gametogenesis was harder to predict in the free-living species, but, given the steady supply of primary production in the vent environment, we anticipated that asynchrony would be favored.

\section{MATERIALS AND METHODS}

Study site. The Lucky Strike hydrothermal field is located at $37^{\circ} 18.5^{\prime} \mathrm{N}, 32^{\circ} 16.5^{\prime} \mathrm{W}$ on the Mid-Atlantic Ridge (Fig. 1). The field is comprised of several areas of active venting and sulfide mounds following a roughly $\mathrm{N}$-S line across the summit of the Lucky Strike Seamount (Langmuir et al. 1997). Two discrete sulfide mounds separated by $\sim 400 \mathrm{~m}$ were sampled (Fig. 1): Eiffel Tower, a $20 \mathrm{~m}$ high tapered spire in the southern area of the field $(1687 \mathrm{~m})$ and Sintra, a $5 \mathrm{~m}$ spire in the northern area $(1618 \mathrm{~m})$. Both vents are dominated by a new species of mussel belonging to the genus Bathymodiolus (Craddock et al. 1995). Mussel lengths were not significantly different in our samples from the 2 sites. The overall mean mussel length $(n=1500)$ was $48 \pm 18 \mathrm{~mm}(\mathrm{SD})$. The 2 species of polynoid polychaetes examined in this study are associated with the mussel clumps.

Sampling. All specimens were collected in July 1996 during several ROV (remotely operated vehicle) 'Jason' dives during the LUSTRE '96 cruise to Lucky Strike. Mussel clumps were harvested from sulfide 
substrates with the manipulator and placed in collection buckets until the mussel volume reached the 2 l mark, at which point the bucket was closed to retain sample integrity. Five replicate samples were collected from Eiffel Tower and 5 from Sintra. Samples were retrieved via free-ascent elevator to minimize the length of time between collection and processing.

Mussels in each sample were rinsed with filtered seawater over a $63 \mu \mathrm{m}$ sieve to collect all organisms living within interstitial spaces. Maximum lengths of all mussels $>5 \mathrm{~mm}$ were measured. Careful sorting of mussel washings resulted in relatively large numbers (total $n=$ 265 individuals) of the free-living polynoid polychaete species (Opisthotrochopodus n. sp.) Commensal polynoids (Branchipolynoe cf. seepensis) were collected by opening all mussels and removing the worms. Additional specimens of the commensal species were found in mussel washings and are included in analyses. These are interpreted as mostly being worms that slipped out of their host mussels during collection and processing. A total of $707 \mathrm{~B}$. cf. seepensis individuals were collected. All polynoid specimens were preserved in $10 \%$ seawater formalin and transferred to $70 \%$ ethanol for storage.

Sex determination, sex ratios and population structure. Sexual dimorphism, expressed by the number of pairs of nephridial papillae projecting ventrolaterally from specific segments, was confirmed in a preliminary manner in each species by histological examination of 5 individuals of each morphological type. Numerous $(>30)$ additional putative females per species were examined histologically for oocyte measurements described below and provided further confirmation of this sexual dimorphism. Once sexual dimorphism was confirmed, sex ratios were determined based on examination of nearly all individuals collected within a species (Branchipolynoe cf, seepensis, total $\mathrm{n}=703$; Opisthotrochopodus $\mathrm{n}$. sp., total $\mathrm{n}=264$ ). Site-specific ratios were also examined. Significant differences from 1:1 sex ratios were evaluated using chi-square tests $(\alpha=0.05)$.

Analysis of population structure in each species was based on total lengths ( $\mathrm{mm}$ ) of all specimens collected. Measurements were made using digital calipers and are accurate to within $\pm 2 \mathrm{~mm}$. Sample sizes for subgroups of worms are indicated in figure captions. For Branchipolynoe cf. seepensis, size-frequency histograms could be developed with replicates at each site for worms with 1 (male) and 2 (female) pairs of nephridial papillae. Due to the small numbers of

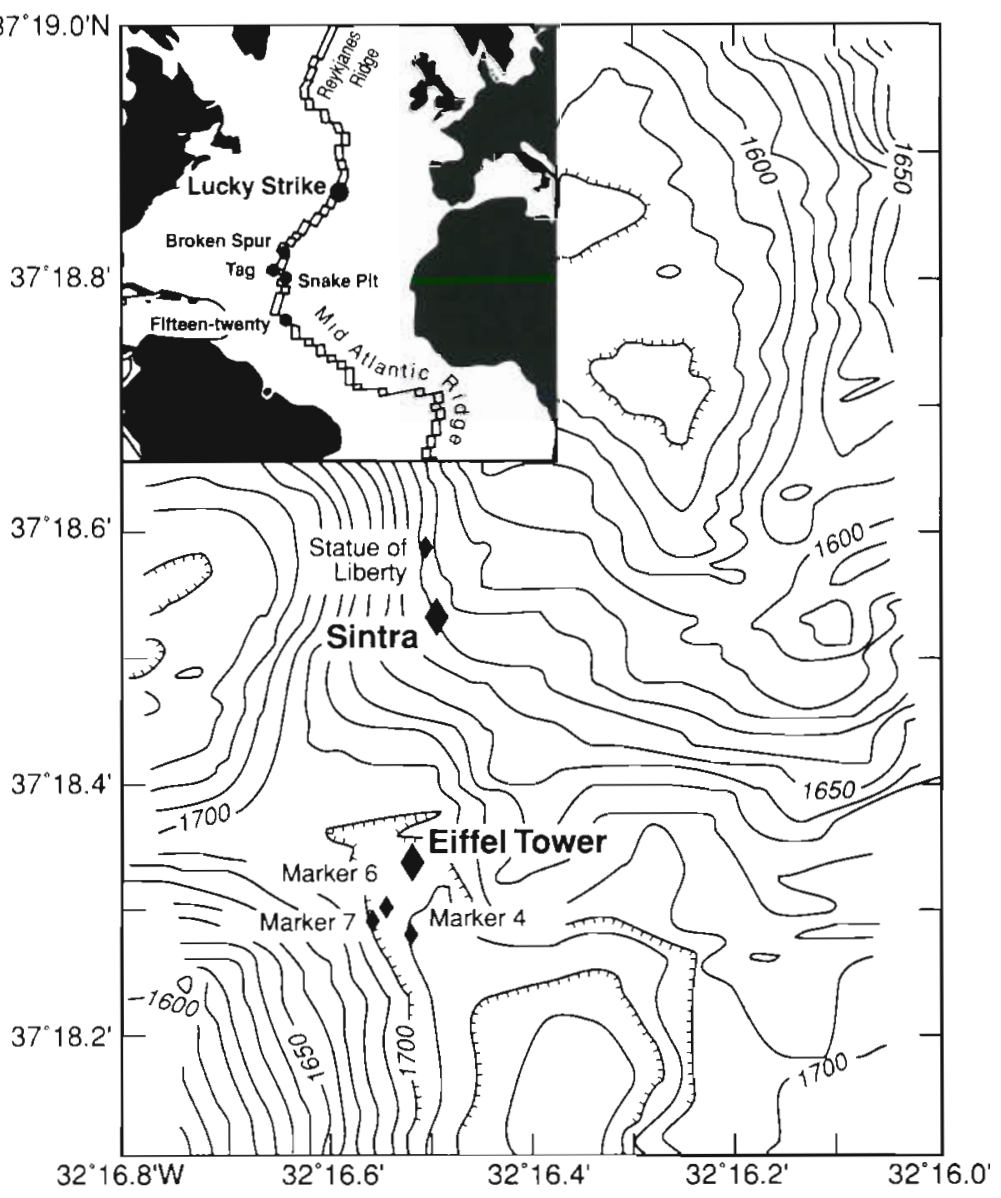

Fig. 1. Lucky Strike hydrothermal field on the Mid-Atlantic Ridge. Inset: regional context

Opisthotrochopodus n. sp. in each replicate, worms from all replicates at both sites were pooled to generate size-frequency histograms for worms with 0 (female) and 1 (male) pair of nephridial papillae. An a priori test for cohort phenomena was conducted by analyzing the size-frequency distributions for normality using the Kolmogorov-Smirnov test (with Lilliefors' correction; $\alpha=0.05$ ). Our assumption is that normal distributions in size frequencies will preclude the existence of significant, discrete cohorts.

Histology. Histological examination of gonadal material was carried out on whole specimens. Prior to histological processing, large specimens were slit ventrally to enhance infiltration. Worms were processed through an alcohol dehydration series and embedded in paraffin. Serial cross-sections $8 \mu \mathrm{m}$ thick were stained using Papanicolaou OG-6, hematoxylin and eosin.

Oocyte diameters and fecundity. To ensure analysis of oocytes over the range of worm sizes representing the sample populations, subsamples of 15 females per site for each species were selected according to the rel- 
Table 1. Branchipolynoe cf. seepensis. Number of oocytes measured per individual. Because of the non-random distribution of oocyte diameter along the length of the worm, serial sections were systematically sampled as described in the text. The number of ocytes measured per individual thus depends on the length of the worm. Size-frequencies based on these oocyte measures are plotted in Fig. 9A. Random subsamples of 100 measurements per individual were used for the ANOVA statistical comparison of oocyte diameters between individuals as reported in the text. At $\mathrm{n}<100$ (i.e. $\mathrm{n}=6,1$ ), individuals were considered to be immature; these also corresponded to the smallest individuals (see Fig. 10A,B)

\begin{tabular}{|lcc|}
\hline Specimen no. & Eiffel Tower & Sintra \\
\hline 1 & 146 & 661 \\
2 & 384 & 119 \\
3 & 218 & 213 \\
4 & 328 & 276 \\
5 & 170 & 163 \\
6 & 6 & 179 \\
7 & 578 & 134 \\
8 & 215 & 249 \\
9 & 359 & 197 \\
10 & 137 & 114 \\
11 & 740 & 100 \\
12 & 101 & 1 \\
13 & 595 & 389 \\
14 & 507 & 275 \\
15 & 191 & 113 \\
\hline
\end{tabular}

ative proportion of worm size classes. Feret diameter $(\mu \mathrm{m})$ - the diameter of a hypothetical circular object with the same area as the measured object - - was used as an estimate of oocyte diameter due to the irregular shape of most oocytes. Feret diameters were measured only of oocytes in which the nucleolus was observed to avoid duplicate measures of the same oocyte and to standardize as much as possible the cross-section of the oocyte. Measurements were made using image processing software (Sigma Scan Pro), with an error of $\pm 1 \mu \mathrm{m}$. Most worms contained a number of oocytes $<25 \mu \mathrm{m}$ in feret diameter that could not reliably be measured or counted and are therefore not included in this analysis. Within-worm variation in oocyte size was compared to between-worm variation using analysis of variance (ANOVA) components.

Because Branchipolynoe cf. seepensis are large and relatively fecund worms (thousands of immature oocytes $[<300 \mu \mathrm{m}$ in diameter] per individual), we chose to subsample the oocyte population. We found that oocyte size distributions are not random along the length of the worms. To reduce bias in our estimate of mean oocyte diameter for each individual, 1 or 2 crosssections were selected randomly from each slide of 25 to 50 serial cross-sections. All slides with sections containing oocytes were subsampled in this manner (i.e. 6 to 19 slides, depending on the length and reproductive condition of the worm). At least 100 oocytes were mea-
Table 2. Opisthotrochopodus n. sp. Total number of oocytes per individual. All oocytes were measured in this species

\begin{tabular}{|lcc|}
\hline Specimen no. & Eiffel Tower & Sintra \\
\hline 1 & 330 & 119 \\
2 & 363 & 198 \\
3 & 180 & 226 \\
4 & 414 & 231 \\
5 & 287 & 231 \\
6 & 402 & 324 \\
7 & 477 & 281 \\
8 & 347 & 291 \\
9 & 188 & 192 \\
10 & 383 & 241 \\
11 & 388 & 208 \\
12 & 228 & 237 \\
13 & 364 & 311 \\
14 & 565 & 173 \\
15 & 0 & 290 \\
\hline
\end{tabular}

sured from each worm, unless the worm was immature (Table 1). For ANOVA comparisons, subsamples of 100 oocyte measures were taken randomly from the measured sets for each individual.

In Opisthotrochopodus n. sp., all oocytes $>25 \mu \mathrm{m}$ were measured (see Table 2 for numbers of oocytes per individual) and a direct tally of oocytes $>25 \mu \mathrm{m}$ was used as an estimate of fecundity. Correlations between oocyte diameters and abundance versus body length were tested using the Spearman Rank Order method $(\alpha=0.05)$. Comparable measures of fecundity in Branchipolynoe cf. seepensis were not obtained.

\section{RESULTS}

\section{Sexual dimorphism}

Branchipolynoecf. seepensis. Three morphotypes of $B$. cf. seepensis are readily distinguished under a dissecting microscope: worms with 0,1 or 2 pairs of nephridial papillae (Fig. 2A,B). Histological examination of 5 individuals with 1 pair of papillae on segment 12 and 51 individuals with 2 pairs of papillae (on segments 11 and 12 ) indicate that individuals with 1 pair are males, and those with 2 pairs are females. (Note that the first segment of polynoids is lateral to the prostomium, fused with it basally, bears dorsal and ventral tentacular cirri, and may be with or without setae. This segment is followed by the second or buccal segment which bears paired elytrophores, elytra, and ventral buccal cirri.) Individuals with 2 pairs of papillae (females) were on average $12.7 \mathrm{~mm}$ larger than worms with 1 pair of papillae (males) (Table 3). Sixty-six worms with no papillae were small and sexually undifferentiated (Fig. 3A). In between-site comparisons, individuals with 1 or 2 pairs 
of nephridial papillae at Eiffel Tower were significantly larger than like individuals at Sintra ( $t$-test, $\mathrm{p}<0.001)$ by a mean difference of 1.7 to $2.5 \mathrm{~mm}$ (Table 4).

Opisthotrochopodus n. sp. Two morphotypes of Opisthotrochopodus n. sp. are readily separated under a dissecting microscope: worms with 1 pair of nephridial papillae on segment 12 and those with no papillae (Fig. 2C,D). Histological examination of 7 individuals with 1 pair of papillae and 45 individuals with no papillae reveals that worms with nephridial papillae are male, those without nephridial papillae are fe-

Fig. 2. Nephridial papillae and sexual dimorphism in Lucky Strike polynoid polychaetes. (A) Branchipolynoe cf seepensis: 1 pair of nephridial papillae (male); (B) B. cf. seepensis: 2 pairs of nephridial papillae (female). (C) Opisthotrochopodus n. sp: 1 pair of nephridial papillae (male); (D) Opisthotrochopodus n. sp.: 0 nephridial papillae (female)
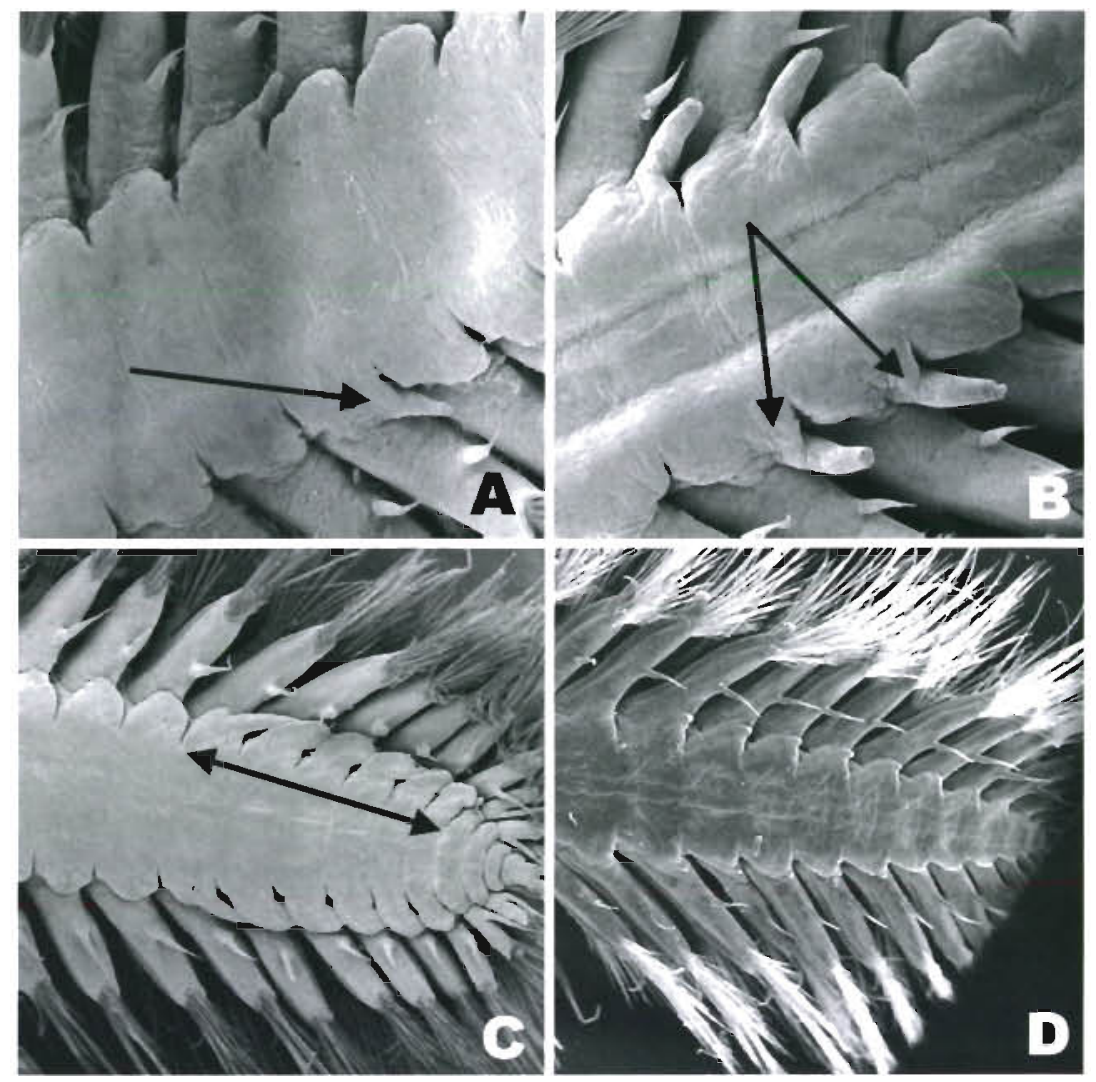

Table 3. Pair-wise comparisons ( $t$-test) of mean worm length versus number of pairs of nephridial papillae. Numbers in parentheses are the difference in mean length $(\mathrm{mm})$ such that, for example, Opisthotrochopodus $\mathrm{n}$. $\mathrm{sp}$. with 1 pair of papillae were on average $0.7 \mathrm{~mm}$ larger than worms with no papillae

\begin{tabular}{|c|c|c|c|c|c|}
\hline & \multicolumn{3}{|c|}{$\begin{array}{c}\text { Branchipolynoe cf. seepensis } \\
\text { No. of pairs of papillae }\end{array}$} & \multicolumn{2}{|c|}{$\begin{array}{l}\text { Opisthotrochopodus n. sp } \\
\text { No. of pairs of papillae }\end{array}$} \\
\hline & 0 & 1 (male) & 2 (female) & 0 (female) & 1 (male) \\
\hline 0 & - & $\begin{array}{l}<0.001 \\
(-7.1)\end{array}$ & $\begin{array}{l}<0.001 \\
(-12.7)\end{array}$ & - & $\begin{array}{l}<0.001 \\
(-0.7)\end{array}$ \\
\hline 1 & - & - & $\begin{array}{l}<0.001 \\
(-5.6)\end{array}$ & - & - \\
\hline
\end{tabular}

Table 4. Pair-wise comparisons ( $t$-test) of mean length between Eiffel Tower and Sintra populations. Numbers in parentheses are the difference in mean length $(\mathrm{mm})$ such that, for example, Branchipolynoe cf. seepensis with 1 pair of papillae were on average $1.7 \mathrm{~mm}$ larger at Eiffel Tower than at Sintra

\begin{tabular}{|c|c|c|c|}
\hline \multicolumn{2}{|c|}{ Branchipolynoe cf. seepensis } & \multicolumn{2}{|c|}{ Opisthotrochopodus n. sp. } \\
\hline $\begin{array}{l}\text { No. of pairs } \\
\text { of papillae }\end{array}$ & $\stackrel{p}{\text { (mean length, mm) }}$ & $\begin{array}{l}\text { No. of pairs } \\
\text { of papillae }\end{array}$ & $\underset{\text { (mean length, mm) }}{\mathrm{p}}$ \\
\hline $\begin{array}{c}1 \\
\text { (male) }\end{array}$ & $\begin{array}{c}<0.001 \\
(1.7)\end{array}$ & $\begin{array}{c}1 \\
\text { (male) }\end{array}$ & Not significant \\
\hline $\begin{array}{c}2 \\
\text { (female) }\end{array}$ & $\begin{array}{c}<0.001 \\
(2.5)\end{array}$ & $\begin{array}{c}0 \\
\text { (female) }\end{array}$ & $\begin{array}{l}<0.01 \\
(0.59)\end{array}$ \\
\hline
\end{tabular}

male (Fig. 3B). In addition to the elongate pair of nephridial papillae in male worms, there are 5 posterior pairs of variously elongate ventral processes of unknown function. Female Opisthotrochopodus n. sp. from combined Lucky Strike samples were significantly ( $p<$ 0.001 ; Table 4) smaller (average body length $5.8 \mathrm{~mm}$ ) than males (average body length $6.6 \mathrm{~mm})$.

\section{Sex ratios}

Branchipolynoe cf. seepensis. The estimated sex ratio for the Lucky Strike population based on all samples collected was $0.6: 1$ (males:females). Chi-squared analysis shows this to be a significant difference ( $p<0.001$ ) from a 1:1 sex ratio. Analysis of Eiffel Tower and Sintra samples separately resulted in 0.5:1 and 0.7:1 ratios, respectively. These ratios were significantly different $(p<0.01$ ) from a 1:1 ratio and from each other.

Opisthotrochopodus n. sp. The estimated sex ratio for the Lucky Strike population based on all samples collected was 0.7:1 (males:females). Chi-squared analysis shows 
Fig. 3. Size-distribution and sex of polynoids based on number of pairs of nephridial papillae. (A) Branchipolynoe cf. seepensis, (B) Opisthotrochopodus $\mathrm{n}$. $\mathrm{sp}$. Centerline indicates the median, box ends indicate $25 \mathrm{th} / 75$ th percentiles, whisker lines indicate 10 th and 90 th percentiles, and dots indicate 5 th and 95 th percentiles. Based on 707 individuals of $B$. cf. seepensis and 264 individuals of Opisthotrochopodus n. sp.

no significant difference from a 1:1 sex ratio. Analysis of Eiffel Tower and Sintra samples separately resulted in 1.1:1 and 0.6:1 ratios, respectively, but these ratios were not significantly different from 1:1 or from each other

\section{Gametogenesis}

Spermatogenesis

Both commensal and free-living Lucky Strike polynoids exhibit filiform sperm heads (lengths: $50 \mu \mathrm{m}$ in Branchipolynoe cf. seepensis, 30 to $40 \mu \mathrm{m}$ in Opisthotrochopodus n. sp.; Fig. 4). Testes in B. cf. seepensis are

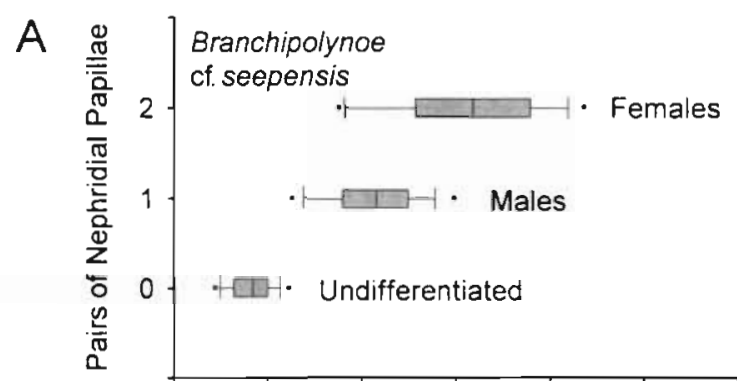

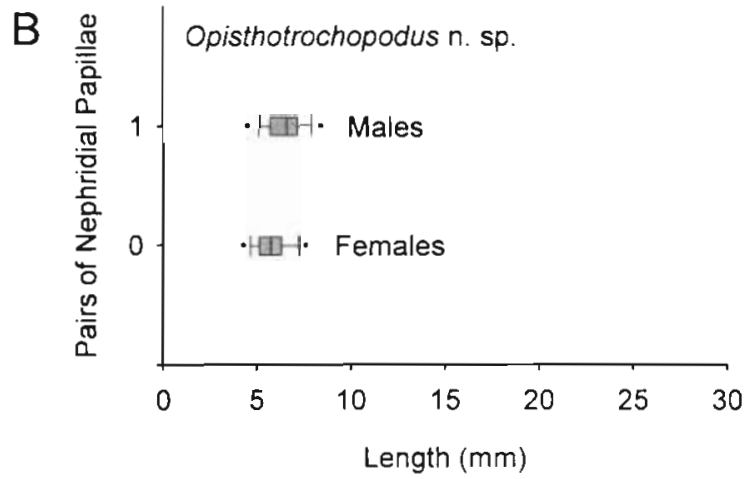
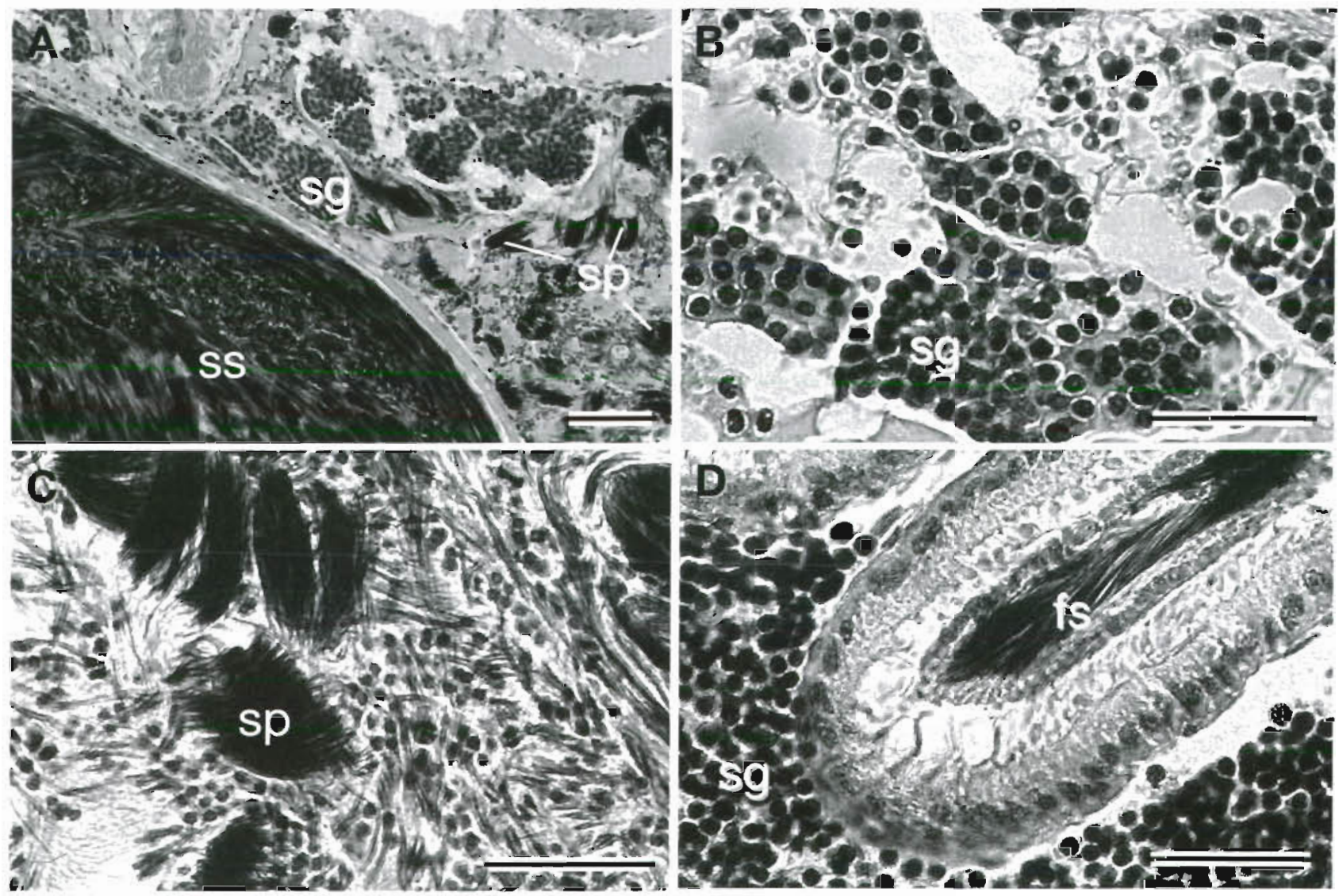

Fig. 4. Male reproductive structures. (A to C) Branchipolynoe cf. seepensis. (D) Opisthotrochopodus $\mathrm{n}$. $\mathrm{sp}$. $\mathrm{sg}=\mathrm{spermatogonia,} \mathrm{sp}$ = sperm packets, $\mathrm{ss}=$ sperm sac with filiform sperm, fs = filiform sperm. Scale bars: $\mathrm{A}=100 \mu \mathrm{m}, \mathrm{B}-\mathrm{D}=50 \mu \mathrm{m}$ 
fused, with 3 distinct regions of sperm production: (1) developing spermatogonia (4 to $6 \mu \mathrm{m}$ ) and spermatocytes (Fig. 4A-C), (2) spermatids and packets of filiform sperm (comprising approximately 20 to 50 sperm in a given longitudinal section) and (3) an area of enclosed sperm storage containing dense aggregates of presumably mature sperm. In Opisthotrochopodus n. sp., sperm occur in a large region extending the length of 6 segments. Developing sperm in this production region (i.e. spermatogonia [ 3 to $5 \mu \mathrm{m}$ ], spermatocytes, and spermatids) are all contained between the gut and the ventral and lateral body walls, while filiform sperm occur in tubules running through the region (Fig. 4D).

\section{Oogenesis}

The ovaries of Branchipolynoe cf. seepensis occur ventral to the gut, and seem to be attached laterally. In Opisthotrochopodus n. sp., the ovaries attach ventro- laterally. Early developing oocytes can generally be seen quite far toward the sides of the body (Fig. 5D).

Both species in this study exhibit intraovarian oogenesis with oocytes surrounded by follicle cells (Fig. 5C), which is consistent with observations on other polynoid species (e.g. Harmothoe imbricata; Garwood 1978,1981 ). The functional role of follicle cells in the development of oocytes of these species cannot be determined from the samples available. Developing oocytes of Branchipolynoe cf. seepensis maintain a close association with branching blood vessels (Fig. 5A), which has also been observed in $H$. imbricata (Garwood 1981). Blood vessel-oocyte associations are not seen within Opisthotrochopodus n. sp., but it is possible that these delicate associations may have been destroyed during histological processing.

Both species exhibit 3 distinct stages of oocyte development: previtellogenic oocytes, mature oocytes with a germinal vesicle, and mature oocytes without a germinal vesicle (Fig. 5A-D). The smaller, previtellogenic oocytes (Fig. 5A,C,D) are numerous, while larger,
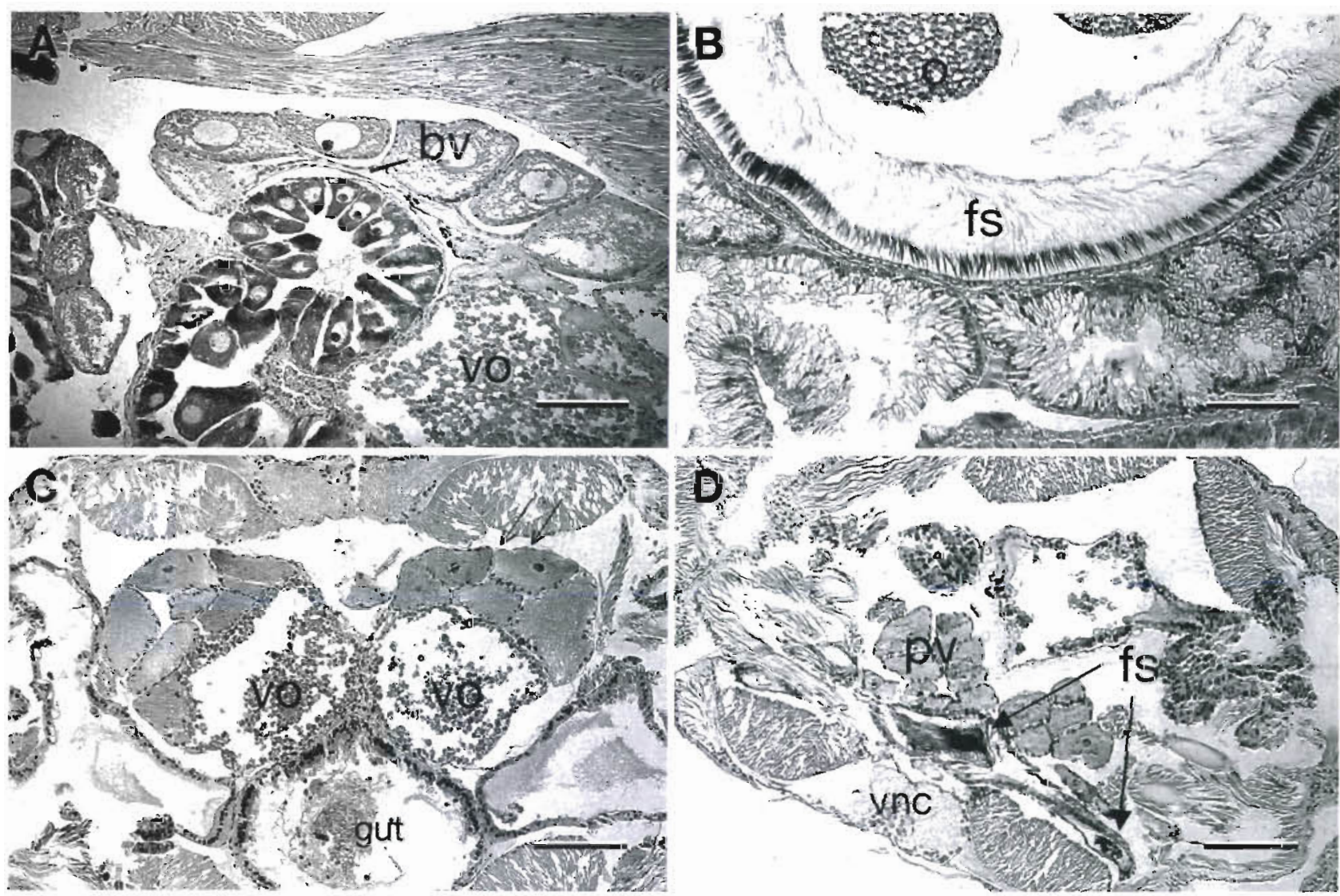

Fig. 5. Female reproductive structures. (A) Branchipolynoe cf. seepensis; previtellogenic oocytes in close association with blood vessels (bv); vo = vitellogenic oocyte. (B) B. cf. seepensis; egg sac with mature oocyte (o) lacking a germinal vesicle and filiform sperm (fs). (C) Opisthotrochopodus n. sp.; paired ventrolateral ovaries with previtellogenic and vitellogenic oocytes; arrows point to follicular cells that surround developing oocytes in both species. (D) Opisthotrochopodus n. sp.; filiform sperm (fs) in tubules with developing oocytes; $v$ nc $=$ ventral nerve cord, $\mathrm{pv}=$ previtellogenic oocytes. Scale bars $=100 \mu \mathrm{m}$ 

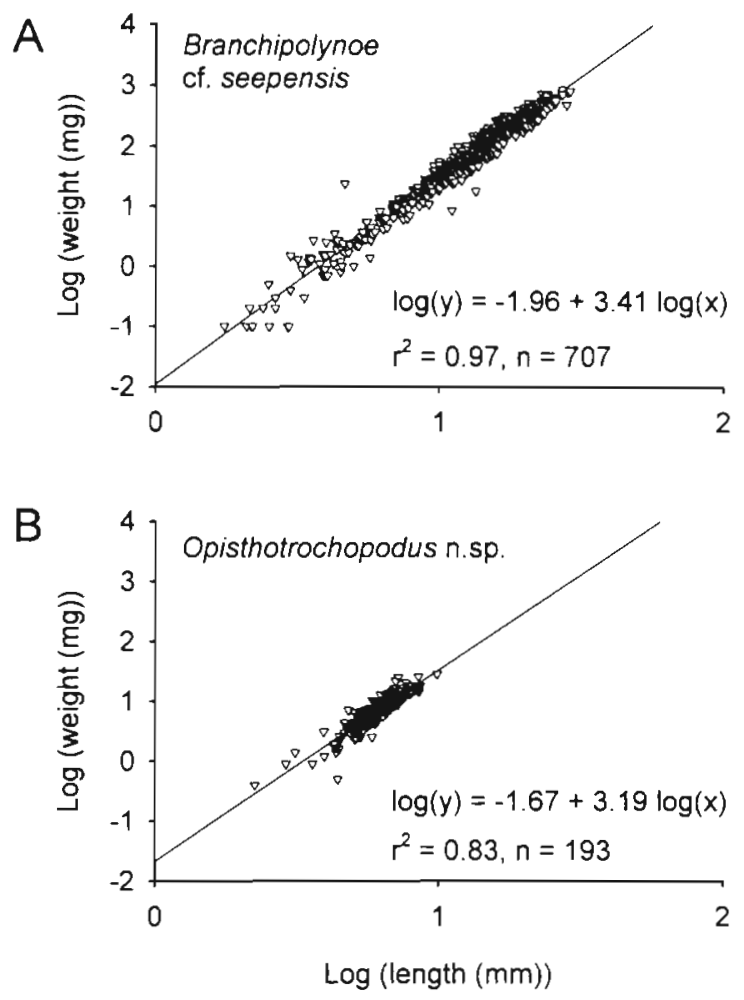

Fig. 6. Relationship between $\log ($ wet weight $[\mathrm{mg}]$ ) and $\log$ (length [mm]). (A) Branchipolynoe cf. seepensis, (B) Opisthotrochopodus n. sp. A constant of 0.1 was added to all wet weights to adjust for samples with weights less than the detectable limits; $n=$ sample size $; r^{2}=$ correlation coefficient mature, vitellogenic oocytes with well-developed yolk granules and conspicuous germinal vesicles (Fig. 5A,C) are present in fewer numbers. Maximum oocyte diameter was comparable for the 2 Lucky Strike species: Branchipolynoe cf. seepensis, $395 \mu \mathrm{m}$; Opisthotrochopodus n. sp., $420 \mu \mathrm{m}$. For $B$. cf. seepensis, where oocytes were subsampled in individuals, mature oocytes $\geq 300 \mu \mathrm{m}$ in diameter represented 0 to $3 \%$ of the subsample populations. Opisthotrochopodus n. sp. ranged from 0 to $5 \%$ mature oocytes per individual out of the total number of oocytes examined. Lowest percentages of mature oocytes ( 0 to $1 \%$ ) were found exclusively in immature worms of small size. No intermediate oocyte stages were apparent, which suggests that both species undergo rapid vitellogenesis. Large, yolky oocytes in which the germinal vesicle is absent, probably broken down, always occur in specialized sacs or tubules running along the ventral wall of the coelom (Fig. 5B). In B. cf. seepensis, this sac is lined with filiform sperm (Fig. 5B). This sperm-lined egg sac splits anteriorly into 2 smaller ducts or tubules, both filled with dense fijiform sperm. Filiform sperm found in females are comparable in head length $(50 \mu \mathrm{m})$ to sperm found in males of the species. In Opisthotrochopodus n. sp., a smaller ventro-central tube is present, which is sometimes filled with sperm (Fig. 5D). This duct occasionally branches off into tubules that run to the body wall on either side. The nature of these sperm-lined sacs, tubes, and ducts is unknown, although they may be sites of sperm storage and egg fertilization.
Fig. 7. Branchipolynoe cf. seepensis. Size-frequency distributions of total length (mm) by sex and site. (A, B) Eiffel Tower; (C, D) Sintra. Vertical bars represent mean frequencies with 1 standard deviation for a given size class, determined from 5 replicate samples from each site. Sample sizes (number of individuals): $A, 192$; B, 201; C, 110; D, 204
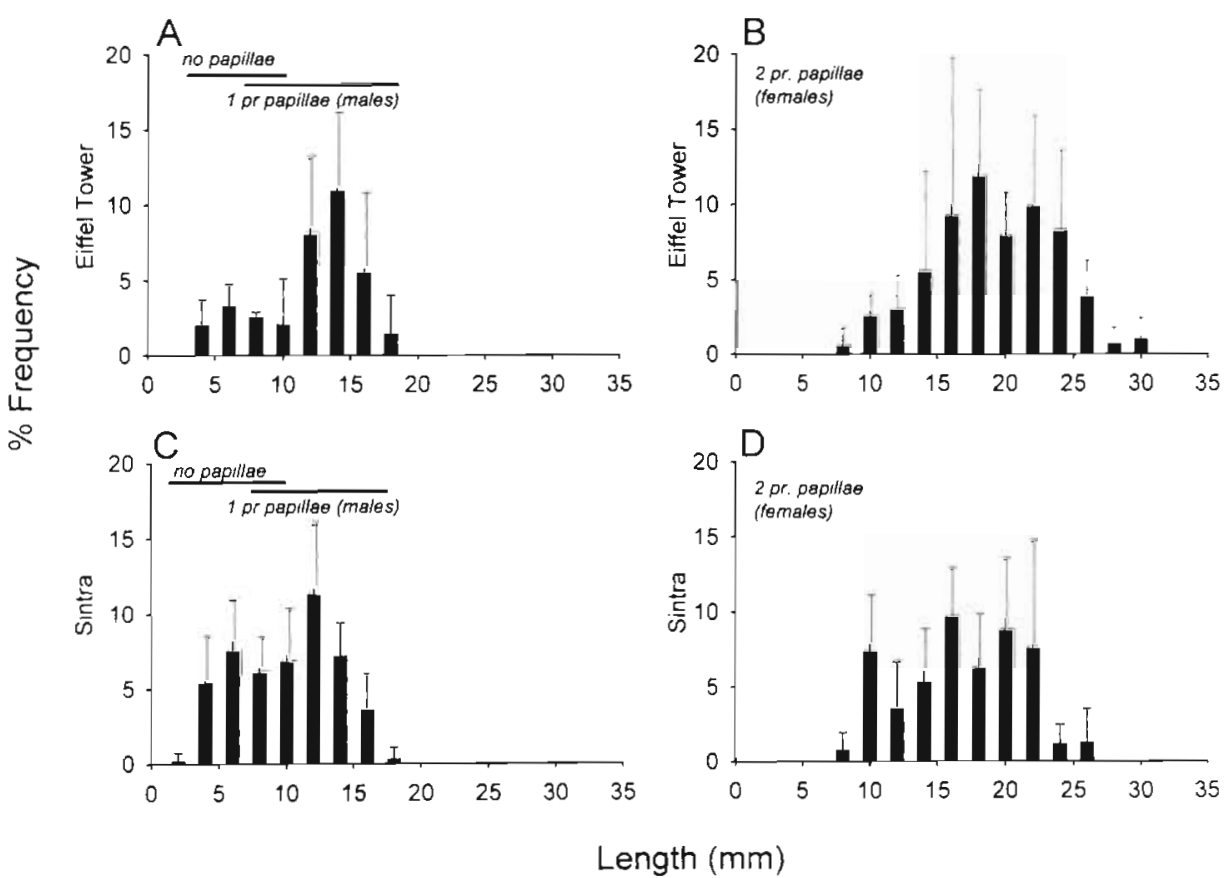


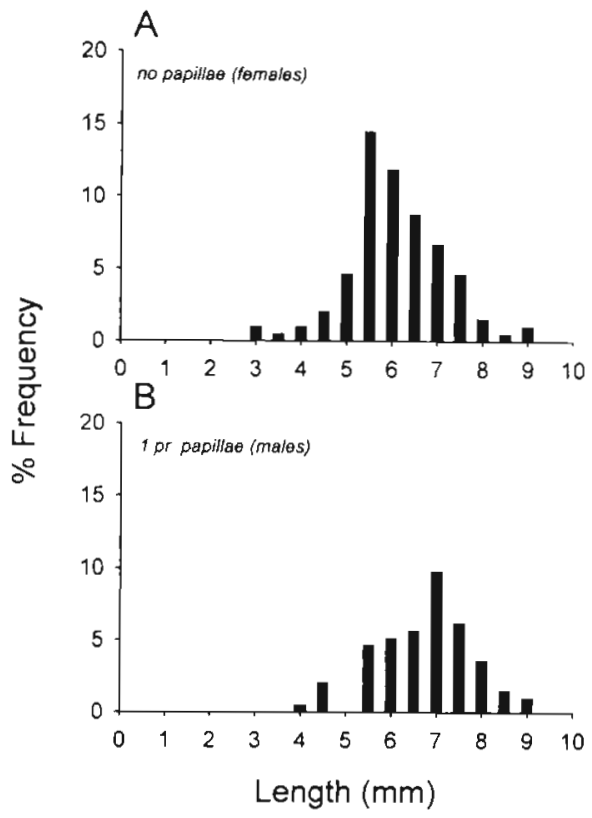

Fig. 8. Opisthotrochopodus n. sp. Size-frequency distributions of total length $(\mathrm{mm})$ by sex. Worms from both Sintra and Eiffel Tower have been combined. Sample sizes ( $\mathrm{n}$ individuals): A, $151 ; B, 114$

\section{Population structure}

For size-frequency analysis of the population structure of the 2 species of polynoids, we use body length as a measure of total body size. The relationship between length and wet weight for each species is highly correlated $\left(\mathrm{r}^{2}>0.8, \mathrm{p}<0.001\right.$; Fig. 6), indicating that length is a reliable estimator of total body size.

Branchipolynoe cf. seepensis. Size-frequency histograms of worm length are normally distributed within sexes at both Sintra and Eiffel Tower, suggesting that recruitment is a continuous or frequently intermittent event rather than an event at discrete and resolvable intervals (Fig. 7).

Opisthotrochopodus n. sp. As in Branchipolynoe cf. seepensis, size-frequency histograms of worm length are normally distributed in both sexes within sites and when both sites are combined (Fig. 8). This is consistent with continuous or frequent recruitment to the population. Mean length of Eiffel Tower females was significantly larger than that of Sintra females $(p<$ 0.01 ; mean difference $=0.6 \mathrm{~mm}$ ), but mean male size did not differ between the 2 sites.

\section{Oocyte size-frequency distributions}

Branchipolynoe cf. seepensis. Smallest oocyte sizeclasses were the most abundant in all individuals regardless of site (Fig. 9A). The smallest oocyte sizeclass measured ( 25 to $50 \mu \mathrm{m}$ ) also had the greatest vari- ance about the mean. Plots of oocyte diameter versus worm length (Fig. 10A) reveal that female individuals $<15 \mathrm{~mm}$ in total length were reproductively immature, lacking mature, yolk-rich oocytes $(>250 \mu \mathrm{m})$. Mean oocyte diameter was significantly correlated with worm length for combined Eiffel Tower and Sintra individuals ( $\mathrm{r}=0.38$; Fig. $11 \mathrm{~A}$ ). No significant difference was found in mean oocyte diameter among worms collected from Eiffel Tower and Sintra ( $p=0.3)$. ANOVA components indicate that, although variation of oocyte diameters within worms is greater than variation between worms, there are significant differences among worms within each site $(p<0.001)$.

Opisthotrochopodus n. sp. As in Branchipolynoe cf. seepensis, smallest oocyte size-classes were the most
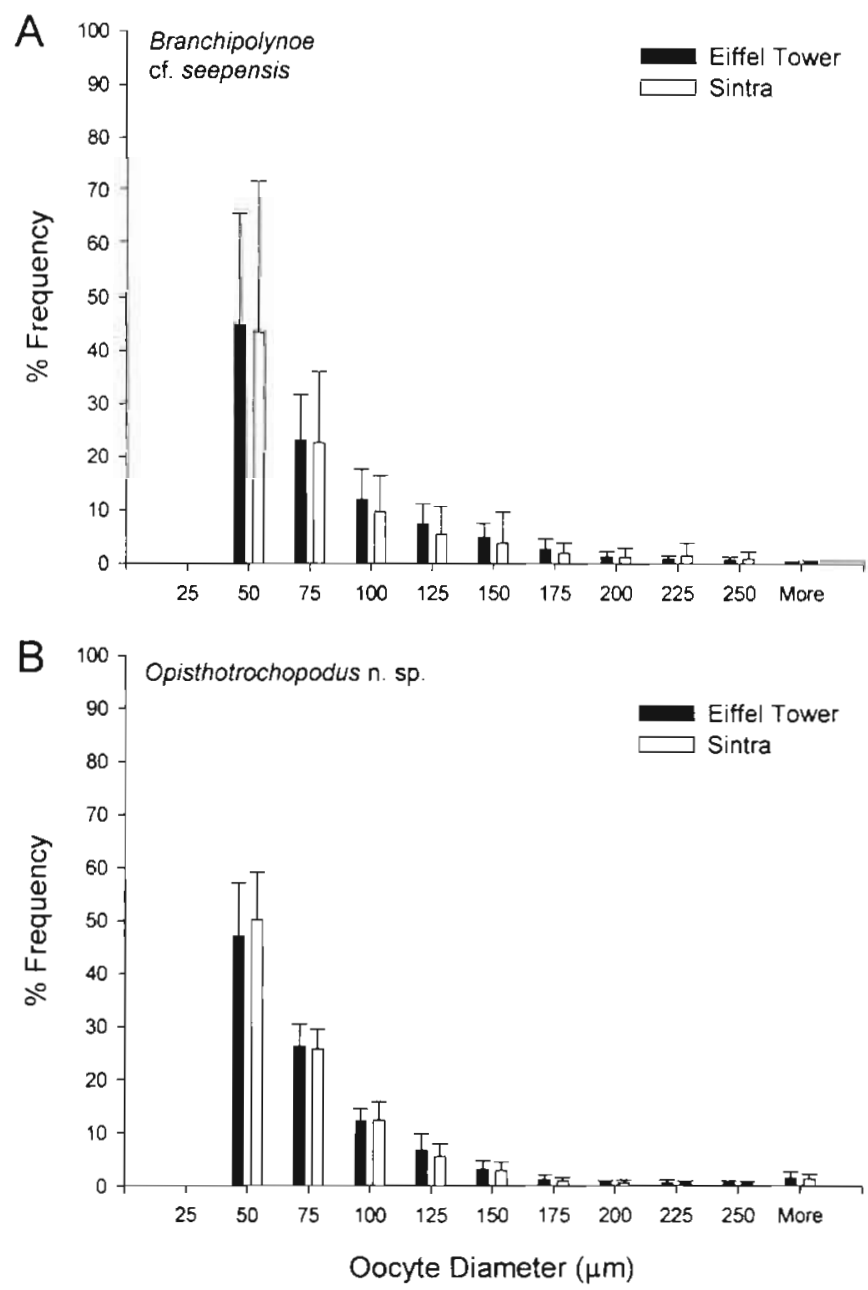

Fig. 9. Oocyte size-frequency distributions. (A) Branchipolynoe cf. seepensis, (B) Opisthotrochopodus n. sp. Size-frequencies were determined for 15 individuals of each species from each site based on measurement of at least 100 oocytes per individual following methods described in the text. Vertical bars represent the mean and standard deviation of frequencies for each size class determined from all individuals at a given site. Oocytes $<25 \mu \mathrm{m}$ are not included in this analysis 

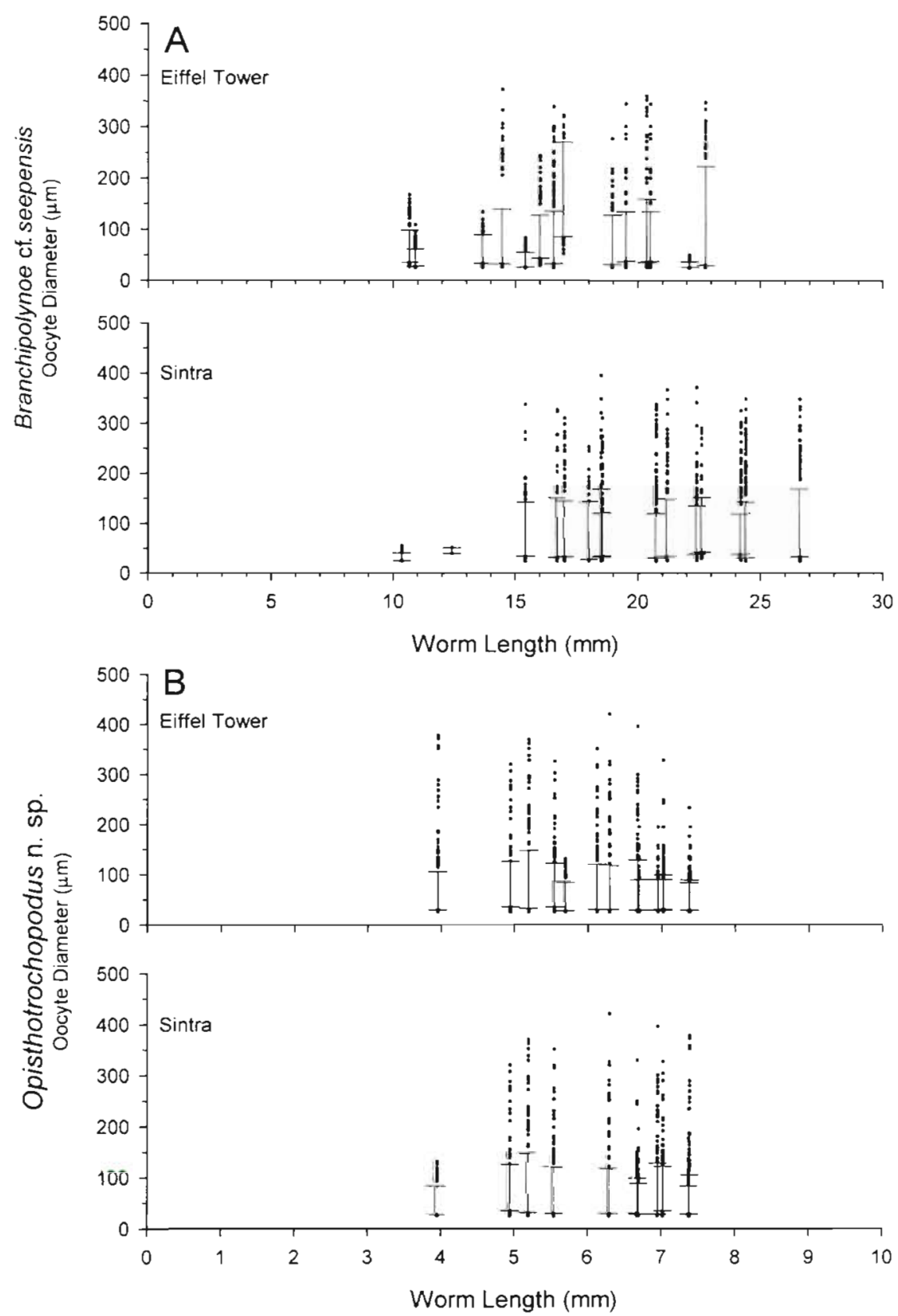

Fig. 10. Oocyte diameter versus worm length. (A) Branchipolynoe cf. seepensis, (B) Opisthotrochopodus n. sp. Whiskers denote 10th and 90th percentiles, symbols are outliers

abundant in all individuals regardless of site (Fig. 9B). The smallest oocyte size-class measured (25 to $50 \mu \mathrm{m})$ also had the greatest variance about the mean. Plots of oocyte diameter versus worm length (Fig. 10B) reveal that one of the smallest individuals examined $(<4 \mathrm{~mm}$ total length) contained what we infer to be yolk-rich oocytes (cytochemical analysis was outside the scope of this project). Mean oocyte diameter was significantly correlated with worm length for combined Eiffel Tower and Sintra individuals ( $\mathrm{r}=0.82$; Fig. 11B). We also found significant $(p<0.001)$ correlations between number of oocytes per individual and number of mature oocytes per individual versus worm length in
Opisthotrochopodus n. sp. (Fig. 12). ANOVA indicates that there is no significant difference in mean oocyte diameter between the 2 sites and that, although variation of oocyte diameters within worms is greater than between worms, there are significant differences among worms within each site $(p<0.001)$.

\section{DISCUSSION}

Sexual dimorphism of the type observed in Lucky Strike polynoid polychaetes is described in detail for Harmothoe imbricata by Daly (1972), Gametes in $H$. 

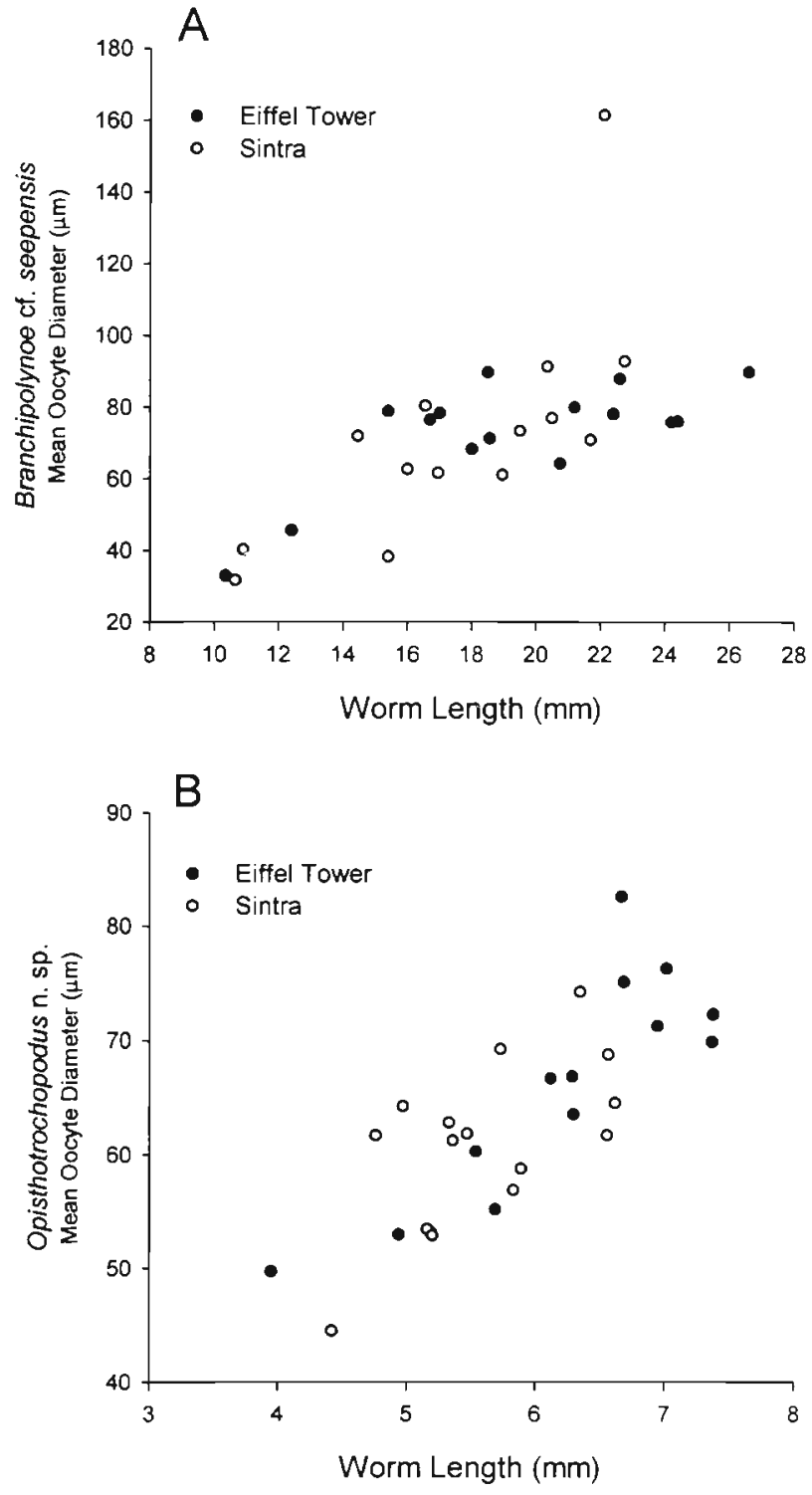

Fig. 11. Mean oocyte diameter versus worm length. (A) Branchipolynoe cf. seepensis $(\mathrm{r}=0.38)$, (B) Opisthotrochopodus n. $\mathrm{sp} .(\mathrm{r}=0.82)$

imbricata are released through the nephridial papillae and, in polytelic species, these papillae elongate during sexual maturation and regress following spawning to near-juvenile conditions. Lack of regressed papillae in specimens from Lucky Strike is consistent with asynchronous gametogenesis in these species. In addition to sexually dimorphic variation in numbers of pairs of papillae, females of Branchipolynoe cf. seepensis are typically larger than males (by $\sim 5$ to $10 \mathrm{~mm}$ body length). Sexual maturation in females of this species is not reached until they approach the mean size of males $(\sim 15 \mathrm{~mm})$. The size differential between sexes in this species seems likely to be an accommodation to the commensal lifestyle of the worm, where
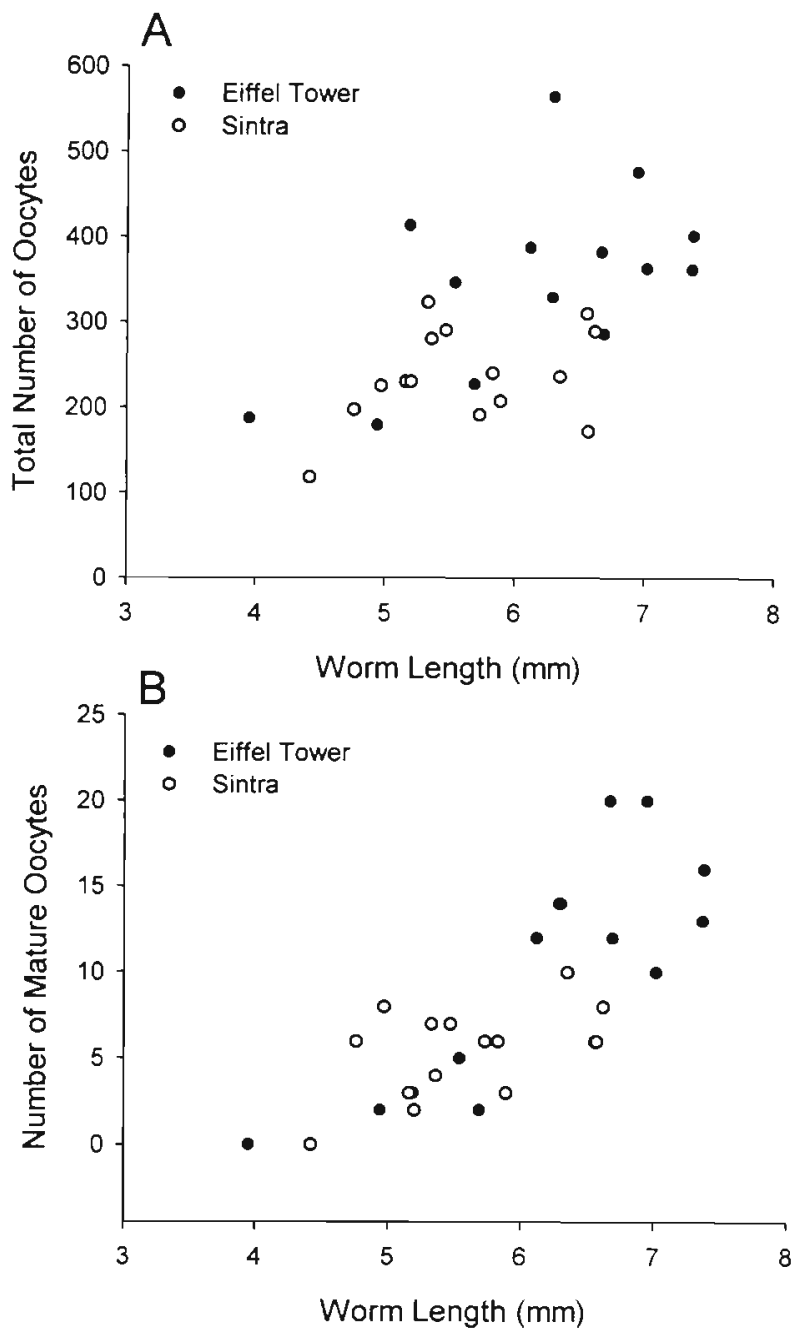

Fig. 12. Opisthotrochopodus n. sp. Correlations of total number of oocytes $(A ; r=0.57)$ and number of mature oocytes $(B$; $r=0.76$ ) with worm body length. Both correlations (with Eiffel Tower and Sintra data combined) are significant at $p<0.001$

small males might move more adeptly between mussels while females grow large and fecund within the mussel mantle cavity. There is also a significant size difference between sexes in Opisthotrochopodus n. sp., but in this species females are slightly smaller than males.

We examined our specimens carefully for evidence of hermaphroditism, especially since Hourdez (in Jollivet 1996) suggests protandric hermaphroditism for Branchipolynoe cf. seepensis. While sexual dimorphism in size and the female bias in the population sex ratio are consistent with protandric hermaphroditism in this species and abundant, mature sperm were observed in every mature female, we observed no instance of male germinal tissue giving rise to female germinal tissue, nor did we see any developing sperm stages (spermatogonia, spermatocytes, or spermatids) 
in the females. Further, small, immature females contain no recognizable remnant of male reproductive tissue based on our histological sections, as might be expected if the species was a protandric hermaphrodite. Sperm of both Lucky Strike polynoid species have elongate heads $(50 \mu \mathrm{m})$, a morphology that is suggestive of specialized transfer. In comparison, mature spermatozoa of several polynoid species (Lepidonotus sp., Harmothoe imbricata, H. impar) and other polychaete species with extemal fertilization have head lengths on the order of 2.7 to $3.6 \mu \mathrm{m}$ (Rouse 1988, Bentley \& Serries 1992). Sperm with elongate heads are in general associated with species that exhibit a modified method of sperm transfer or storage, in contrast to ectaquasperm (sensu Rouse \& Jamieson 1987) which are most often shed freely into the water (Rice 1992). Ultrastructural studies are needed to elaborate details of sperm morphology in the vent polynoid species. It is not possible to determine if sperm transfer in the Lucky Strike polynoid species occurs by release of spermatophores into the water or by copulation. Our observations at present are most consistent with sperm storage and internal fertilization in both $B$. cf. seepensis and Opisthotrochopodus n. sp., especially given the presence of mature oocytes without germinal vesicles in sperm-lined sacs of $B$. cf. seepensis.

Maximum oocyte sizes of both Lucky Strike polynoid species exceed $300 \mu \mathrm{m}$. Given that paraffin techniques can result in up to $30 \%$ shrinkage in tissues, our oocyte measurements are likely to be underestimates of actual egg size. Polynoid polychaetes are generally free-spawning and have small eggs $(\bar{x}=$ $117 \pm 30 \mu \mathrm{m})$ that undergo planktotrophic development (Wilson 1991, Giangrande 1997). Although Olive (1985) suggests that larvae deriving from eggs with diameters $>180 \mu \mathrm{m}$ should rarely be planktotrophic, egg size is not always a good indicator of developmental mode (Giangrande 1997). Nevertheless, large eggs (>300 $\mu \mathrm{m}$ ) almost always give rise to either lecithotrophic larvae or direct development (Giangrande 1997). We found polynoid juveniles among our samples, but were unable to identify them to species or to determine if these represent direct development or post-larval stages. We observed no evidence of brooding beneath the elytral scales, as is the case in at least 1 polynoid (Harmothoe imbricata; Blake 1975).

Intraovarian oogenesis, as observed in both Lucky Strike polynoid species, and close association of developing oocytes with blood vessels (observed in Branchipolynoe cf. seepensis) are characters sometimes indicative of rapid vitellogenesis (Eckelbarger 1983). In fast egg-producing species, oogenesis can be compressed to only hours or days (versus months in slow egg-producers), as long as food supply is maintained
(Eckelbarger \& Watling 1995). As already emphasized, the lack of intermediate stages of oocyte development in Lucky Strike polynoids provides further evidence that oogenesis is rapid in these species. While we cannot assess the actual rate of oogenesis in Lucky Strike polynoids, morphological indications of rapid oogenesis suggest that in situ experimental methods might be applied during the course of a single dive series (usually 2 to $3 \mathrm{wk}$ ) to provide a measure of this rate. According to Eckelbarger \& Watling (1995), fast eggproducing species are effectively decoupled from the environmental cues that regulate egg production in synchronous spawners - as long as there is food, there are eggs.

In any 1 individual, only a small percentage of the total number of oocytes are mature in either species of Lucky Strike polynoid. We were able to identify immature specimens, but found no evidence for 'spent' individuals or for overwhelmingly 'ripe' individuals. In both species, oocyte diameters were highly variable and broadly distributed within individuals, and there were significant differences in mean oocyte diameters among worms within sites. These observations lead us to conclude that gametogenesis is asynchronous in both species, both at the individual and at the population level. This condition, combined with the style of vitellogenesis, putative sperm storage capabilities, and habitat conditions of presumably unlimited food resources lead us to infer frequent spawning in these species, with fertilized eggs released to the surrounding environment ad libitum. The combination of 110 juvenile polynoids (unidentified to species) in our samples and normal distributions of size-frequency histograms within sexes for Branchipolynoe cf. seepensis and within both sexes combined for Opisthotrochopodus n. sp. is consistent with frequent rather than episodic recruitment in these species.

We found no substantive evidence for site-specific variations in the reproductive biology of either polynoid species from Lucky Strike. Thus, despite reported differences in the fluid chemistries of these 2 sites (Von Damm et al. 1998) and in the carbon and nitrogen isotopic composition of the mussels which dominate the invertebrate biomass (Trask \& Van Dover 1999), these sites appear to be homogeneous at the level of resolution of polynoid reproduction.

Not unexpectedly, mean oocyte diameters, total number of oocytes and number of mature oocytes may all be correlated with body size. This is especially welldocumented for Opisthotrochopodus n. sp., where we were able to count and measure all oocytes $>25 \mu \mathrm{m}$ in each individual. There is thus clearly a requirement for systematic sampling by size for studies of reproductive biology in polynoid polychaetes. We chose to sample with probability proportional to size frequency to 
obtain measures of the reproductive biology within populations, but other strategies may also be useful (e.g. restricting specimens to multiple individuals in a single size class).

To our surprise, we find little evidence of different reproductive strategies in the commensal and freeliving polynoid species, apart from the much greater size and fecundity of female Branchipolynoe cf. seepensis and their skewed sex ratio favoring females. Large and fecund female polynoid polychaetes at vents are not restricted to the commensal mien, however, nor are free-living species in the genus Opisthotrochopodus restricted to small size and low fecundity (based on unpublished observations by C.L.V.D. on polynoid polychaetes from the East Pacific Rise).

Within the context of the reproductive biology of hydrothermal vent polychaetes, Lucky Strike poly- noids are remarkable in the large size of their oocytes. Their sexual dimorphism, elongate sperm, asynchronous gametogenesis within individuals and among individuals within a population, apparent sperm storage and specialized mode of fertilization are attributes shared with various alvinellid and ampharetid species (Table 5).

Acknowledgements. Dr Marion Pettibone assisted us with polynoid identifications. We are especially grateful to Kevin Eckelbarger for his gracious and enthusiastic tutorial on polychaete reproduction. We are indebted to the personnel of the Deep Submergence Laboratory (Woods Hole Oceanographic Institution) for collections of specimens and to Dan Fornari and Susan Humphris who were Chief Scientists of the LUSTRE Expedition. We are also grateful to anonymous reviewers who helped us clarify our prose and interpretations. This work was supported by NSF-GEO-9505579.

Table 5. Reproductive characteristics of hydrothermal vent polychaete species (all gonochoric). EPR = East Pacific Rise; JdF = Juan de Fuca Ridge; Ex = Explorer Ridge; MAR = Mid-Atlantic Ridge

\begin{tabular}{|c|c|c|c|c|c|c|}
\hline Species & $\begin{array}{c}\text { Egg } \\
\text { diam } \\
(\mu \mathrm{m})\end{array}$ & $\begin{array}{l}\text { Inferred } \\
\text { mode of } \\
\text { development }\end{array}$ & $\begin{array}{l}\text { Gameto- } \\
\text { genesis } \\
(\mathrm{M}: \mathrm{F})\end{array}$ & $\begin{array}{l}\text { Sex } \\
\text { ratio }\end{array}$ & Comments and inferences & Source \\
\hline $\begin{array}{l}\text { Alvinellidae } \\
\text { Alvinella } \\
\text { pompejana } \\
\text { EPR }\end{array}$ & 200 & $\begin{array}{l}\text { Lecitho- } \\
\text { trophic }\end{array}$ & $\begin{array}{c}\text { Not } \\
\text { available }\end{array}$ & - & - & $\begin{array}{l}\text { Chevaldonné \& Jollivet (1993), } \\
\text { Chevaldonné et al. (1997) }\end{array}$ \\
\hline $\begin{array}{l}\text { Paralvinella } \\
\text { grasslei } \\
\text { EPR }\end{array}$ & 275 & Direct & $\begin{array}{l}\text { Synchro- } \\
\text { nous }\end{array}$ & - & $\begin{array}{l}4000 \pm 1400 \text { oocytes in coelomic } \\
\text { cavity; sexual dimorphism; com- } \\
\text { pulsory passage of oocytes through } \\
\text { inseminated spermathecae; sugges- } \\
\text { tions of pairing and brooding }\end{array}$ & Zal et al. (1995) \\
\hline $\begin{array}{l}\text { Paralvinella } \\
\text { pandorae } \\
\text { pandorae } \\
\text { JdF, Ex }\end{array}$ & 215 & Brooder & $\begin{array}{l}\text { Asynchro- } \\
\text { nous }\end{array}$ & $1: 1$ & $\begin{array}{l}4500 \text { oocytes per worm; sperm } \\
\text { morphology suggests specialized } \\
\text { mode of fertilization }\end{array}$ & McHugh (1989) \\
\hline $\begin{array}{l}\text { Paralvinella } \\
\text { palmiformis } \\
\mathrm{JdF}, \mathrm{Ex}\end{array}$ & 260 & $\begin{array}{l}\text { Lecitho- } \\
\text { trophic }\end{array}$ & $\begin{array}{l}\text { Synchro- } \\
\text { nous }\end{array}$ & - & $\begin{array}{l}18000 \text { oocytes per worm; demersal } \\
\text { larvae }\end{array}$ & McHugh (1989) \\
\hline $\begin{array}{l}\text { Ampharetidae } \\
\text { Amphisamytha } \\
\text { galapagensis } \\
\text { JdF }\end{array}$ & 240 & $\begin{array}{l}\text { Lecitho- } \\
\text { trophic }\end{array}$ & $\begin{array}{l}\text { Asynchro- } \\
\text { nous }\end{array}$ & $1: 1$ & $\begin{array}{l}5600-9600 \text { oocytes per worm on } \\
\text { average (max. }=12500 \text { ); early } \\
\text { maturation; external fertilization; } \\
\text { demersal larvae }\end{array}$ & McHugh \& Tunnicliffe (1994) \\
\hline $\begin{array}{l}\text { Polynoldae } \\
\text { Branchipolynoe } \\
\text { cf. seepensis } \\
\text { MAR }\end{array}$ & 395 & $\begin{array}{l}\text { Lecitho- } \\
\text { trophic } \\
\text { or direct }\end{array}$ & $\begin{array}{l}\text { Asynchro- } \\
\text { nous }\end{array}$ & $1: 2$ & $\begin{array}{l}\text { 0-300 mature oocytes (free in } \\
\text { coelom) per worm; sexual dimor- } \\
\text { phism (no. of nephridial papillae } \\
\text { and size); rapid oogenesis; sperm } \\
\text { storage and internal fertilization }\end{array}$ & This study \\
\hline $\begin{array}{l}\text { Opisthotrocho- } \\
\text { podus n. sp. } \\
\text { MAR }\end{array}$ & 420 & $\begin{array}{l}\text { Lecitho- } \\
\text { trophic } \\
\text { or direct }\end{array}$ & $\begin{array}{l}\text { Asynchro- } \\
\text { nous }\end{array}$ & $1: 1$ & $\begin{array}{l}100-600 \text { oocytes }(>25 \mu \mathrm{m} \text { ) per worm; } \\
0-16 \text { mature oocytes per worm; } \\
\text { sexual dimorphism (no. of nephridial } \\
\text { papillae); rapid oogenesis; sperm } \\
\text { storage and internal fertilization }\end{array}$ & This study \\
\hline
\end{tabular}




\section{LITERATURE CITED}

Bentley MG, Serries K (1992) Sperm ultrastructure in two species of the polychaete genus Harmothoe (Polynoidae). Helgol Meeresunters 46;171-184

Berg CJ Jr (1985) Reproductive strategies of mollusks from abyssal hydrothermal vent communities. Bull Biol Soc Wash 6:185-197

Berglund A (1990) Sequential hermaphroditism and the sizeadvantage hypothesis: an experimental test. Anim Behav 39:426-433

Bhaud M, Cazaux C (1987) Description and identification of polychaete larvae: their implications in current biological problems. Oceanis 13:596-753

Blake J (1975) The Iarval development of Polychaeta from the northern California Coast. III. Eighteen species of Errantia. Ophelia 14:23-84

Chevaldonné P, Jollivet D (1993) Videoscopic study of deepsea hydrothermal vent alvinellid polychaete populations: biomass estimation and behavior. Mar Ecol Prog Ser 95: 251-262

Chevaldonné P, Jollivet $D$, Vangreisheim A, Desbruyères $D$ (1997) Hydrothermal vent alvinellid polychaete dispersal in the eastern Pacific. 1. Influence of vent site distribution, bottom currents and biological features. Limnol Oceanogr 42:67-80

Craddock C, Hoeh WR, Gustafson RG, Lutz RA, Hashimoto J, Vrijenhoek RJ (1995) Evolutionary relationships among deep-sea mytilids (Bivalvia: Mytilidae) from hydrothermal vents and cold-water methane/sulfide seeps. Mar Biol 121: $477-485$

Daly JM (1972) The maturation and breeding biology of Harmothoe imbricata (Polychaeta: Polynoidae). Mar Biol 12: $53-66$

Desbruyères D, Laubier L (1983) Primary consumers from hydrothermal vent animal communities. In: Rona PA, Böstrom K, Laubier L, Smith KL (eds) Hydrothermal processes at seafloor spreading centers. Plenum Press, New York, p 711-734

Eckelbarger K (1983) Evolutionary radiation in polychaete ovaries and vitellogenic mechanisms: their possible role in life history patterns. Can J Zool 61:487-504

Eckelbarger K, Watling L (1995) Role of phylogenetic constraints in determining reproductive patterns in deep-sea invertebrates. Invertebr Biol 114:256-269

France SC, Hessler RR, Vrijenhoek RC (1992) Genetic differentiation between spatially-disjunct populations of the deep-sea. hydrothermal vent-endemic amphipod Ventiella sulfuris. Mar Biol 114:551-559

Garwood PR (1978) The role of environmental factors in the control of reproduction in Harmothoe imbricata (Polychaeta: Polynoidae). PhD thesis, University of Newcastleupon-Tyne

Garwood PR (1981) Observations on the cytology of the developing female germ cell in the polychaete Harmothoe imbricata (L.). Int J Invertebr Reprod 3:333-345

Giangrande A (1997) Polychaete reproductive patterns, life cycles and life histories: an overview. Oceanogr Mar Biol Annu Rev 35:323-386

Langmuir C, Humphris S, Fornari D, Van Dover $\mathrm{CL}_{\text {, Von }}$ Damm K, Tivey M, Colodner D, Charlou JL, Fouquet $Y$, Klinkhammer $G$, Bougault $H$, Desonie D, and the Lucky Strike Team (1997) Description and significance of hydrothermal vents near a mantle hot spot: The Lucky

Editorial responsibility: Lisa Levin (Contributing Editor), La Jolla, California, USA
Strike Vent Field at $37^{\circ} \mathrm{N}$ on the Mid-Atlantic Ridge. Earth Planet Sci Lett 148:69-91

Le Pennec M, Benninger PG (1997) Ultrastructural characteristics of spermatogenesis in three species of deep-sea mytilids. Can J Zool 75:308-316

Lutz RA, Jablonski D, Rhoads DC, Turner RD (1980) Larval dispersal of a deep-sea hydrothermal vent bivalve from the Galapagos Rift. Mar Biol 57:127-133

Lutz RA, Jablonski D, Turner RD (1984) Larval development and dispersal at deep-sea hydrothermal vents. Science 226:1451-1454

McHugh D (1989) Population structure and reproductive biology of two sympatric hydrothermal vent polychaetes, Paralvinella pandorae and P. palmiformis. Mar Biol 103: 95-106

McHugh D, Tunnicliffe V (1994) Ecology and reproductive biology of the hydrothermal vent polychaete Amphisamytha galapagensis (Ampharetidae). Mar Ecol Prog Ser 106: $111-120$

Olive PJW (1985) Covariability of reproductive traits in marine invertebrates; implications for the phylogeny of lower invertebrates. In: Conway Morris S (ed) The origins and relationships of lower invertebrates. Oxford University Press, Oxford, p 42-59

Reish DJ (1980) The effect of different pollutants on ecologically important polychaete worms. EPA Research Report EPA 600/3-80-053:1-138

Rice SA (1992) Polychaeta: spermatogenesis and spermiogenesis. In: Harrison FW, Gardiner SL (eds) Microscopic anatomy of invertebrates, Vol 7, Annelids. Wiley-Liss, NY, p $129-151$

Rouse GW (1988) An ultrastructural study of the spermatozoa of Eulalia sp. (Phyllodocidae), Lepidonotus sp. (Polynoidae), Lumbrineris sp. (Lumbrineridae) and Owenia fusiformis (Oweniidae). Helgol Meeresunters 42:67-78

Rouse GW, Jamieson BGM (1987) An ultrastructural study of the spermatozoa of the polychaetes Eurythoe complanata (Amphinomidae), Clymenella sp, and Micromaldane sp. (Maldanidae), with definition of sperm types in relation to reproductive biology. J Submicrosc Cytol 19:573-584

Trask JL, Van Dover CL (1999) Site-specific and ontogenetic variations in nutrition of mussels (Bathymodiolus $\mathrm{sp}$.) from the Lucky Strike hydrothermal vent field, Mid-Atlantic Ridge. Limnol Oceanogr 44:334-343

Tunnicliffe V, MacArthur AG, McHugh D (1998) A biogeographical perspective of the deep-sea hydrothermal vent fauna. Adv Mar Biol 34:355-442

Van Dover CL, Williams AB (1991) Egg size in squat lobsters (Galatheoidea): constraint and freedom. In: Wenner A (ed) Crustacean issues. Balkema Press, Rotterdam, p 143-156

Van Dover CL, Factor JR, Williams AB, Berg CJ Jr (1985) Reproductive strategies of hydrothermal vent decapod crustaceans. Bull Biol Soc Wash 6:223-227

Von Damm KL, Bray AM, Buttermore LG, Oosting SE (1998) The geochemical relationships between vent fluids from the Lucky Strike vent field, Mid-Atlantic Ridge. Earth Planet Sci Lett 160:521-536

Wilson WH (1991) Sexual reproductive modes in polychaetes: classification and diversity. Bull Mar Sci 48:500-516

Zal F, Jollivet $D$, Chevaldonné $P$, Desbruyères $D$ (1995) Reproductive biology and population structure of the deep-sea hydrothermal vent worm Paralvinella grasslei (Polychaeta: Alvinellidae) at $13^{\circ} \mathrm{N}$ on the East Pacific Rise. Mar Biol 122:637-648

Submitted: June 15, 1998; Accepted: November 21, 1998 Proofs received from author(s): May 4, 1999 